\title{
PERFORMANCE EVALUATION FRAMEWORK UNDER THE INFLUENCE OF INDUSTRY 4.0: THE CASE OF THE CZECH MANUFACTURING INDUSTRY
}

\author{
Martina Hedvičáková1, Martin Král
}

\begin{abstract}
1 University of Hradec Králové, Faculty of Informatics and Management, Department of Economics, Czech Republic, ORCID: 0000-0001-9751-8292, martina.hedvicakova@uhk.cz;

2 University of Hradec Králové, Faculty of Informatics and Management, Department of Economics, Czech Republic, ORCID: 0000-0003-2237-3564, martin.kral.2@uhk.cz.
\end{abstract}

\begin{abstract}
The current economic situation creates general pressure to increase performance. Any inefficient use of production factors will lead to problems and long-term economic unsustainability in many industries. The effects of the Covid-19 pandemic will also have a negative impact on all sectors of the economy and the faster onset of the fourth industrial revolution.

The article, therefore, proposes a new framework for the performance evaluation of the manufacturing industry, which is based on the composite performance indicator. This indicator is obtained by a cross-sectoral comparison of all sub-key performance indicators. Using cluster analysis and analysis of variance, a total of 6 indicators to evaluate performance in the manufacturing industry were selected as statistically significant. The added value of the whole concept is its direct independence on the economic situation, which eliminates short-term economic oscillations that would be reflected in classical methods of performance evaluation otherwise. The results show that some industries are more efficient in the long run due to their effective investments in the capital, which replaces the labour factor and creates room for the realization of relatively higher profits. By contrast, some sectors, despite high investments, do not achieve the desired level of performance - these investments are not efficient or they are complementary to the labour factor, thus denying the principles of Industry 4.0. It thus creates preconditions for increasing dependence on external factors and, at the same time, makes the given sectors in a freely competitive environment economically unsustainable in the long run.
\end{abstract}

Keywords: Performance, efficiency, industry, added value, investment, Key Performance Indicators.

JEL Classification: L60, O31.

APA Style Citation: Hedvičáková, M., \& Král, M. (2021). Performance Evaluation Framework under the Influence of Industry 4.0: The Case of the Czech Manufacturing Industry. E\&M Economics and Management, 24(1), 118-134. https://doi.org/10.15240/tul/001/2021-1-008

\section{Introduction}

The manufacturing industry is key to the Czech economy and has deep roots in its history. The manufacturing industry accounts for about $35 \%$ of the national economy. It also has a dominant position compared to other countries of the European Union. The manufacturing industry also contributed the most to the creation of the gross domestic product in 2018. It also plays a significant role in employment policy, with around $40 \%$ of the economically active population in the manufacturing industry. In the manufacturing industry, the largest employers are manufacture of transport equipment and manufacture of metal structures. The average wage in all sections of the manufacturing industry is also increasing year by year. The manufacturing industry also plays an important role in terms of innovation, new technologies and investments. Another important information: in 
the Czech Republic in 2018, the manufacturing industry accounted for about one-third of the gross value added. Domestic production of manufacturing in 2018 increased by $3.3 \%$ yearon-year.

To strengthen and maintain the competitiveness of the Czech economy, the Czech government approved the Industry 4.0 initiative in August 2016. Industry 4.0 is also referred to as the fourth industrial revolution and significantly changes the nature of the industry and other parts of the national economy. This initiative has already been approved in most countries of the European Union but also other countries (USA, China, etc) (Association of Small and Medium-sized Enterprises and Selfemployed Persons of the Czech Republic, 2019; The Ministry of Industry and Trade of the Czech Republic, 2018a).

The concept of Industry 4.0 was first mentioned at the trade fair in Hanover in Germany in 2011. This concept of Industry 4.0 is a massive implementation of new information technologies and the digitization of manufacturing processes (Maresova et al., 2018). Although industrial processes are more automated, human performance is still the main factor responsible for product quality and factory productivity (Flynn et al., 2017; Peruzzini et al., 2017).

The need to evaluate the efficiency and performance of production and production factors and the long-term position and development of the industry to ensure the sustainability of individual industrial sectors leads to the compilation of new methods of measuring performance. These methods are adapted to the current situation - especially to external factors and internal requirements. Companies in the Czech Republic slowly begin to leave the analysis of the development of individual ratios and looking for new sophisticated (Asmalovskij et al., 2019; Hálek et al., 2020; Karl et al., 2018; Pavelková et al., 2018; Vimrová, 2015). Zizlavsky (2016) proved that many enterprises still do not measure innovation performance despite the importance of innovation as an engine of growth. Only a few organisations appear to have an effective system for measuring their overall innovation performance. One option is Key Performance Indicators (KPIs), which can provide performance information in a broader context. However, in the context of performance evaluation, sustainability must be taken into account simultaneously.

Currently, the economies of most countries are affected by the economic consequences of coronavirus pandemic. Many companies will have economic problems and will have to look for new ways to make their production processes even more efficient. For this reason, there is also a more massive promotion of digitization and home-office. Companies will have to look for new methods to measure their performance and compare them with each other.

\section{Theoretical Background}

Key Performance Indicators (KPIs) are essential for monitoring performance in the industry. They can be used to identify poor performance and improvement potential. KPIs can be defined for individual equipment, sub-processes, and whole plants. KPIs can measure different types of performances, for example, energy, rawmaterial, control \& operation, maintenance, etc (Ali \& Nakosteen, 2005; Hedvičáková \& Král, 2019; Lindberg et al., 2015).

The appropriate selection and improved understanding of the KPIs could help the manufacturing enterprises fulfil the desired business objectives (Kang et al., 2016). Indicators KPIs can be used in almost all industries and sectors. KPIs for construction deal with, e.g. (Al-Tmeemy et al., 2011; Chan et al., 2004; Chan \& Chan, 2004; Cheung et al., 2004; Jahangirian et al., 2017; Kumaraswamy et al., 2017; Lam et al., 2007; Luu et al., 2008).

The international standard ISO 22400 has defined a set of Key Performance Indicators (KPIs) to evaluate the performance of manufacturing operations (Zhu et al., 2017). A set of $34 \mathrm{KPIs}$ has been introduced in ISO 22400 (Zhu et al., 2018). However, the KPIs in a manufacturing system are not independent, and they may have intrinsic mutual relationships (Kang et al., 2016). To make defined KPIs more suitable for evaluating operational performance in the manufacturing industry, we propose various methods for measuring performance and organizing KPIs for the manufacturing industry.

This article proposes a methodology for compiling a composite performance indicator, which uses partial key performance indicators and thus freely follows the analysis of performance from Hedvičáková and Král 
(2019) for the manufacturing industry. The manufacturing industry is an industry that significantly influences the level of the entire economy, and the Czech economy has an irreplaceable role. The manufacturing industry involves the mechanical, physical, or chemical conversion of materials or components into new products (goods). The result of the production process is either finished products intended for use or consumption, or semi-finished products.

The manufacturing industry is a concrete industry, and the classic ratios are insufficient from our point of view to evaluate its performance. The proposals for measuring performance using various indicators depend on their specific values, and the economic situation strongly influences these values in industrial sectors. In some periods, performance is higher (over something) due to economic growth, while sometimes it is underestimated due to recession. The main goal is to present a system of performance evaluation, which eliminates these factors as much as possible and identify those sectors that are long-term stable and have the potential for further development in the economic environment versa.

Therefore, manufacturing industries nowadays implement a performance measurement system to evaluate the operating state of their manufacturing activities (Ali \& Nakosteen, 2005; Franceschini et al., 2007; Neely et al., 1995; Zhu et al., 2017). The importance of key performance indicators (KPIs) is to quantify the efficiency and effectiveness of the management of production operations and for the implementation of strategic goals of management and process improvement (Braz et al., 2011; Hálek et al., 2020; Hedvičáková \& Král, 2019; Lindberg et al., 2015; Zhu et al., 2018, 2017).

Of course, the introduction of the proposed performance indicators will also bring problems. Peral et al. (2017) argue that KPls are not always well known, and sometimes, it is difficult to find a suitable KPI to match every business goal. Braz et al. (2011) shown the difficulty and complexity in reviewing and updating an existing PMS. The problem is related to the involvement of PMS users, the assessment of performance measures, and data availability. Complexity is similar to changes in information technology to implement the change in procedure for computing the measures. KPIs tell you what to do to increase performance dramatically (Graham et al., 2015).
KPIs should be selected through discussions with stakeholders (employees, managers, customers) (Globerson, 1985) and related to the business objectives (strategy) (Globerson, 1985; Graham et al., 2015; Sorovou et al., 2001) to enable progress to be assessed against these objectives both internally and externally (Graham et al., 2015; PriceWaterhouseCoopers, 2007). Falle et al. (2016) also show that it is important to take into account the specific characteristics of SMEs when developing SBSCs and to use methods that allow them to adapt to prevailing conditions, such as strategic management, organizational structure, and resources.

Many authors also discuss the performance of companies in developing sustainability. Rajnoha et al. (2017) found that the BSC methodology has a demonstrable impact on business performance. The performance of companies is also affected by the KPI system and environmental orientation. If companies do not have a knowledge information system as a complex system and do not consider their implementation, they tend to have a lower level of performance. For example, Hsu et al. (2017) focused on increasing the gross margin share derived from the adopted sustainability strategy. Ferreira et al. (2016) emphasized the need to consider the overall costs and investments associated with environmental protection. Woerd and Brink (2004) explained the importance of financial indicators related to sustainability to evaluate value creation (Hristov et al., 2019; Hristov \& Chirico, 2019). Hedvičáková and Král (2019) emphasize that $\mathrm{KPI}$ analysis can also be used to analyse how individual industries respond to the economic recession, which is now very relevant at the time of the coronavirus pandemic. An example is an automotive industry, which represents a significant share of the Czech industry (Hedvičáková \& Král, 2019).

Bod'a and Úradníček (2020) also highlight the sorely unnoticed fact that the key ratio of financial analysis, return on equity, may easily attain non-sense values and these should be removed before compiling financial analysis; otherwise, industry statistics are biased upward regardless of what measure of central tendency is made use of.

\section{Materials and Methods}

The number of industry-focused publications that assess their performance is clear evidence 
that industrial relations play an essential role in the EU Member States and society. This fact is, among other things, the basis for the requirements for data collection and evaluation, which allows a comparison of the positions of individual EU countries, for example, using a unified Industrial relations index, which is processed by Eurofond. Industrial relations index is a composite index that comprehensively measures country performance in four dimensions - industrial democracy, industrial competitiveness, social justice, and quality of work and employment - and industrial relations systems as a whole. All of them with the range $[0,100]$, where the higher the score, the better the performance of the industrial relations system (Eurofond, 2020).

The article's main goal is to introduce a new system for evaluating the performance of industries based on a composite performance indicator. The added value of this new performance evaluation methodology is the use of relatively simple and unified key performance indicators and the separation of direct and explicit dependence on external economic influences. This way, it can provide production managers, company management, and political representatives with useful information about the performance of industries. This information has considerable potential for defining those sectors whose development has been inefficient for a long time and the principles of its operation in the future in an environment of free competition unsustainable.

Some of the core findings presented in several studies that deal with performance evaluation are taken into account in the framework. Namely, Hedvičáková and Král (2019) have set the eight performance indicators (ratios) to assess the area of industry: added value per employee, added value in relation to cost, turnover per employee; earnings before taxes and interest (EBIT) per employee, investment per employee, a share of investments of the total costs, added value in relation to investments, and EBIT in relation to investments. Turley et al. (2015) and Robbins et al. (2016) use seven different financial indicators to evaluate public performance to propose a framework for calculating one composite index using a benchmark score. Other researches (Amrina \& Yusof, 2011; Huff, 2011; Raynsford, 2000; Zafra-Gómez et al., 2009) used different methods for assessing the performance, but all of them are usable for evaluating in a long-term period. For example, Amrina and Yusof (2011) propose a set of initial key performance indicators (KPIs) for sustainable manufacturing evaluation believed to be appropriate to automotive companies, consisting of three factors divided into nine dimensions and a total of 41 sub-dimensions. Huff (2011) evaluates the performance by rating, taking into account four areas economic situation, financial performance, debt service costs, and management quality. ZafraGomez et al. (2009) divided indicators into several groups - short-term liquidity, budget solvency, long-term solvency, service-level solvency. It also considers the development of their values. According to Raynsford (2000), the KPI framework should consist of seven main groups: Time, Cost, Quality, Client Satisfaction, Client Changes, Business Performance, Health, and Safety (Raynsford, 2000). All of the authors mentioned above see one of the advantages of performance indicators their relative simplicity and easy presentability, which makes them more useful in the practical field.

At the same time, knowledge of the appropriate number of key performance indicators in already published studies is taken into account. The optimum number of KPIs is, unanimously in the literature, fewer than 20 (Graham et al., 2015). Kaplan and Norton (1992) recommend fewer than $20 \mathrm{KPIs}$, Parmenter (2015) about 10, while Hope and Fraser (2003) and PriceWaterhouseCoopers (2007) suggest fewer than $10 \mathrm{KPIs}$. KPIs should also be placed in context, showing trends as well as absolute performance (Graham et al., 2015; PriceWaterhouseCoopers, 2007).

To determine the development and current performance of individual industries the first performance ratios are used, which are added value per employee, added value in relation to cost, turnover per employee; earnings before taxes and interest (EBIT) per employee, investment per employee, a share of investments of the total costs, added value in relation to investments, EBIT in relation to investments. Subsequently, using these performance indicators, a cluster analysis is performed, which identifies the industrial sectors of both the primary economic industries according to CZ-NACE, as well as their subcomponents, with different degrees of longterm performance. The division into a total of 4 
clusters using the Euclidean distance is chosen, with each group can represent a certain degree of performance of a given industry. Within this cluster analysis, those performance indicators are also identified that are statistically significant for this division into clusters (the significance level alpha $=0.05$ is used).

The following section introduces a new framework for evaluating performance based on a composite performance indicator. The calculation of this indicator is based on the point evaluation of the efficiency of each industry according to each of the performance indicators that were identified as statistically significant in the cluster analysis. For each industry, the current value of each selected (significant) performance indicator is first calculated. Subsequently, all industries are sorted in descending order from the value representing the highest performance to the lowest performance. In the next step, points are assigned to the sector, according to the quartile in which they are divided (the first quartile $=3$ points, the second quartile $=2$ points, the third quartile $=1$ point and the fourth quartile $=0$ points). The sum of the points creates the so-called composite score (indicator) of performance. This composite performance indicator, by contrast to the performance evaluation by several different indicators, provides summary information on how stable, efficient, and sustainable given industrial sector is. It is also possible to evaluate the trend of development of each industrial sector in the long-term period.

At the end of the empirical part, the interdependence between selected indicators related to investments is presented. These results are confronted with the performance results of individual industries, including graphical representation - differences and the same features are presented. The results of this analysis complement the overall view of the mutual performance of industries and can also serve as background information on the trend in which the performance of individual sectors will develop in various economic situations.

Publicly available data on the manufacturing industry in the Czech Republic are used as a basis for analyses. These are the essential characteristics of each industry according to CZ-NACE codes, these characteristics include, for example, accounting data and economic results (especially profit, sales, costs, investment), financial data (e.g., added value, performance ratios) and other identification data (e.g., number of companies, number of employees).

Most of these data are obtained by the Czech Statistical Office through a combination of exhaustive and sample survey methods. The survey is carried out by the Czech Statistical Office once a year in accordance with approved regulations (Czech Statistical Office, 2019), using electronic or paper forms. The structured data are subsequently published in cooperation with the Ministry of Industry and Trade of the Czech Republic (The Ministry of Industry and Trade of the Czech Republic, 2018b, 2018a).

\section{Results}

\subsection{Performance Indicators}

To identify key performance indicators that are important for detecting differences in individual industries' performance, cluster analysis, and subsequent analysis of variance were performed. The division into a total of 4 clusters using the Euclidean distance is chosen. Within this cluster analysis, those performance indicators are also identified that are statistically significant for this division into clusters (the significance level alpha $=0.05$ is used).

The cluster analysis inputs were performance indicators that were designed to evaluate the manufacturing industry sectors according to various key performance indicators (Hedvičáková \& Král, 2019) and are in line with the findings presented by other authors (see the section on materials and methods). They are:

- Added value per employee;

- Added value in relation to cost;

- The turnover per employee;

- Earnings before taxes and interest (EBIT) per employee;

- Investment per employee;

- A share of investments of the total costs;

- Added value in relation to investments;

- EBIT in relation to investments.

All values of these indicators were standardized at first, so that all variables gained the same weights, thus eliminating the risk that some of the values will dominate and therefore skew the results. The cluster analysis results show a relatively high similarity between the different industries (see Fig. 1).

A separate cluster consists of the production of computer and optical and electronic products. This sector is characterized by a high level 
of total costs, especially investments, which harms added value in relation to total costs. On the other hand, it achieves a high level of added value per employee or sales per employee and, in terms of the firm's managerial theory, can be assessed as one of the most successful.

A smaller group is formed by the sector of textile production, leather and related products, and clothing production. These sectors differ from the others by worse results of indicators taking into account the number of employees - low levels of investment, sales, and added value. This is a consequence of a higher degree of deployment of manual work, which is currently not appreciated, among other things, as a result of cheap competition from Southeast Asia.

Another group of industries is, for example, the production of beverages, the production of paper and paper products, or the production of basic pharmaceutical products and pharmaceutical preparations. These sectors achieve the highest values of performance indicators taking into account the number of employees due to the high share of investment costs (on average 6.72\%). Thus, the shift to production automation and robotics has a positive effect on reducing operating costs, such as wages, and thus leads to greater independence of labour availability.

The last group of industries is also, to some extent, dependent on human resources' manual labour, but characterized by a higher degree of added value. These are, for example, electrical equipment, fabricated metal products, except machinery and equipment, food products, and furniture production.

\section{Fig. 1: Dendrogram using average linkage}

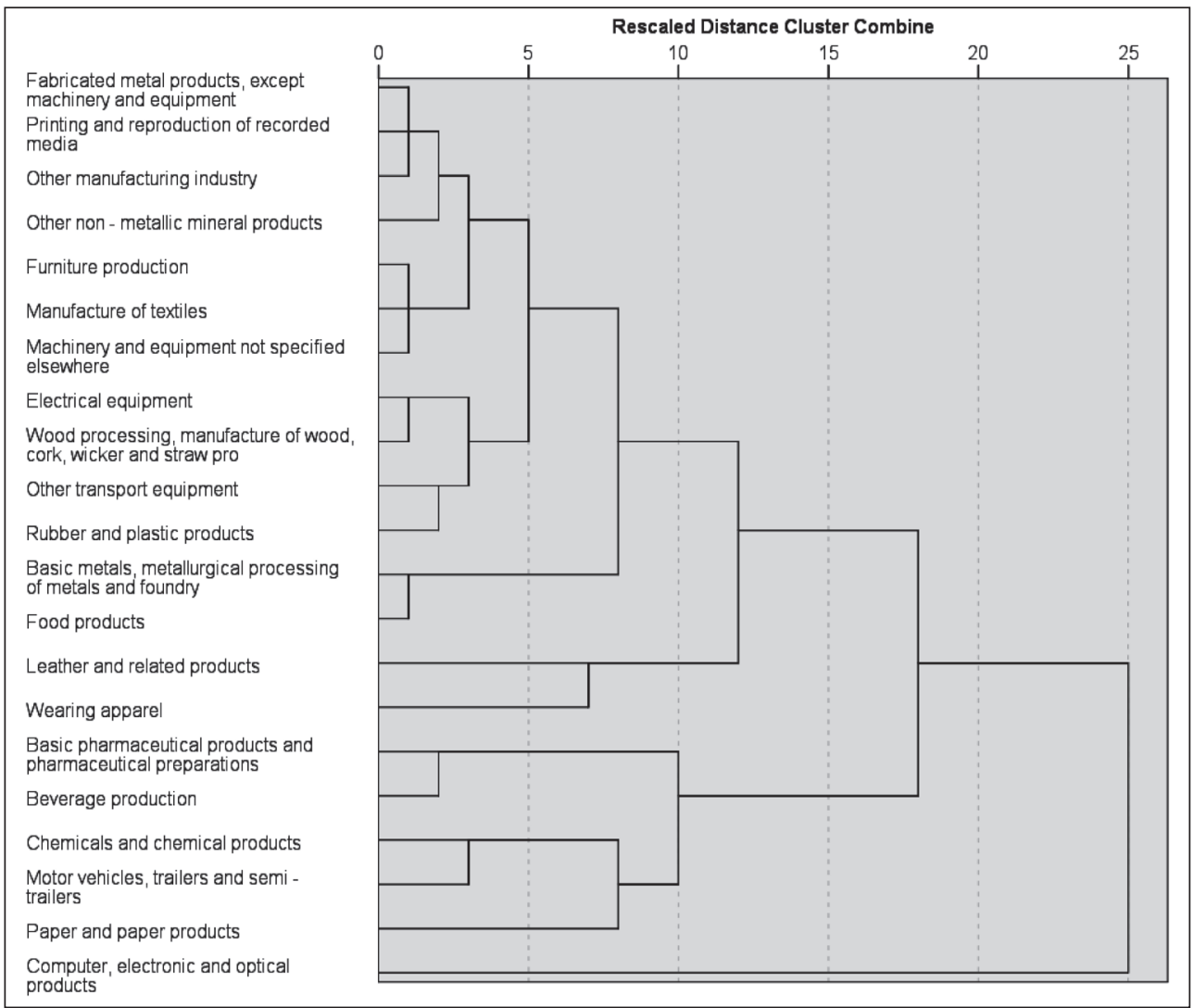


Analysis of variance (ANOVA) was also performed as part of the cluster analysis. It aimed to determine which performance indicators are statistically significant for cluster formation (at the level of significance alpha $=0.05$ ). It turned out that a total of 6 out of 8 performance indicators differ statistically significantly among the individual clusters. Only two indicators (the share of investments in total costs, and EBIT in relation to investments) do not differ statistically significantly between different groups. Unlike other indicators, they are not used in the framework to set the composite performance indicator.

\subsection{Performance Evaluation}

To determine the composite performance indicator, a total of 6 sub-performance indicators, which were identified as statistically significant in the cluster analysis, were used. The principle of calculating the composite performance indicator is based on the scoring of each industrial sector according to the quartile in which it is located according to each performance indicator.

At first, quartile values for each performance indicator were identified (see Tab. 2). Data for the period 2008-2018 were used. In the following steps (i.e., the use of a point evaluation as a proxy variable), it was not necessary to continue with standardized data - for better interpretation, non-standardized data are used.

For each indicator value of the manufacturing industry, each industrial sector was assigned a point value, according to the quartile in which the value of each index was included: 1st quartile $=3$ points, 2 nd quartile $=2$ points, 3 rd quartile $=1$ point, and 4 th quartile $=0$ points. The composite indicator is then defined as the sum of these individual points. As these points are assigned to the industry for each of the six indicators, the composite performance indicator can reach a maximum of 18 points.

While the distribution of the values of the quartiles of the added value in relation to costs is relatively even, for the other indicators, it significantly deviates - the differences between the first two quartiles are significantly higher than between the second two quartiles. Although this fact may have an impact on the overall evaluation of performance according to a composite indicator, which uses point values according to quartiles, it is necessary to keep in mind that these are long-term average values of these indicators. Due to the variance of these values over time and because point values are assigned according to quartiles to the whole group of industries, the distribution of specific values of indicators for each industry is, therefore, marginal in the overall scale.

The values of the composite performance indicators are presented in Tab. 3. At the same time, these values of composite indicators are used to determine the long-term performance of individual industries. This longterm performance is calculated as the sum of individual composite performance indicators in the period 2008-2018. Based on this sum, each industrial sector is classified into an individual quartile from the most efficient (Q1) to the least efficient (Q4). The development of individual

\section{Tab. 1: Analysis of variance (ANOVA)}

\begin{tabular}{|c|c|c|c|c|c|c|}
\hline & Cluster & \multirow{2}{*}{ df } & Error & \multirow{2}{*}{ df } & \multirow{2}{*}{$\mathbf{F}$} & \multirow{2}{*}{ Sig. } \\
\hline & Mean square & & Mean square & & & \\
\hline Added value/costs & 3.166 & 3 & 0.677 & 17 & 4.680 & 0.015 \\
\hline Investments/costs & 2.245 & 3 & 0.839 & 17 & 2.675 & 0.080 \\
\hline EBIT/employee & 4.777 & 3 & 0.392 & 17 & 12.175 & 0.000 \\
\hline Added value/employee & 5.246 & 3 & 0.310 & 17 & 16.950 & 0.000 \\
\hline Turnover/employee & 5.462 & 3 & 0.271 & 17 & 20.124 & 0.000 \\
\hline Investments/employee & 6.521 & 3 & 0.085 & 17 & 77.149 & 0.000 \\
\hline Added value/investments & 5.739 & 3 & 0.223 & 17 & 25.789 & 0.000 \\
\hline EBIT/investments & 2.199 & 3 & 0.847 & 17 & 2.595 & 0.086 \\
\hline
\end{tabular}




\section{Tab. 2: Quartile limit values for each performance indicator}

\begin{tabular}{l|c|c|c|c|c|c} 
& $\begin{array}{c}\text { Added } \\
\text { value/costs } \\
\text { [\%] }\end{array}$ & $\begin{array}{c}\text { EBIT/ } \\
\text { employee } \\
\text { [ths. CZK] }\end{array}$ & $\begin{array}{c}\text { Added } \\
\text { value/ } \\
\text { employee } \\
\text { [ths. CZK] }\end{array}$ & $\begin{array}{c}\text { Turnover/ } \\
\text { employee } \\
\text { [ths. CZK] }\end{array}$ & $\begin{array}{c}\text { Investments/ } \\
\text { employee } \\
\text { [ths. CZK] }\end{array}$ & $\begin{array}{c}\text { Added } \\
\text { value/ } \\
\text { investments } \\
\text { [ths. CZK] }\end{array}$ \\
\hline $\begin{array}{l}\text { Q1 } \\
\text { (3 points) }\end{array}$ & $>31.27 \%$ & $>320.32$ & $>840.41$ & $>3,718.45$ & $>233.84$ & $>5.02$ \\
\hline $\begin{array}{l}\text { Q2 } \\
\text { (2 points) }\end{array}$ & $\leq 31.27 \%$ & $\leq 320.32$ & $\leq 840.41$ & $\leq 3,718.45$ & $\leq 233.84$ & $\leq 5.02$ \\
\hline $\begin{array}{l}\text { Q3 } \\
\text { (1 point) }\end{array}$ & $\leq 26.23 \%$ & $\leq 197.16$ & $\leq 726.83$ & $\leq 2,688.52$ & $\leq 153.45$ & $\leq 4.65$ \\
\hline $\begin{array}{l}\text { Q4 } \\
\text { (0 points) }\end{array}$ & $\leq 22.24 \%$ & $\leq 127.87$ & $\leq 606.51$ & $\leq 2,263.36$ & $\leq 136.19$ & $\leq 4.32$ \\
\hline
\end{tabular}

groups of sectors according to the performance quartile is illustrated in Fig. 2.

The evaluation of the performance of individual industrial sectors shows that in the long run (between 2008 and 2018), with a few exceptions, there are no significant fluctuations in their performance. Most of all industries, regardless of external circumstances, achieve approximately the same results compared to other industrial sectors. This is evident, for example, in the case of beverage production, which achieved the best results over the whole sectors between 2008 and 2018, and, conversely, in the case of manufacture of textiles, which reached the worst results (compared to other industries). However, despite the stability of most sectors, exceptions can be found. It is, for example, the production of basic metals

\section{Fig. 2: Development of performance of the manufacturing industry sectors according to performance quartiles}

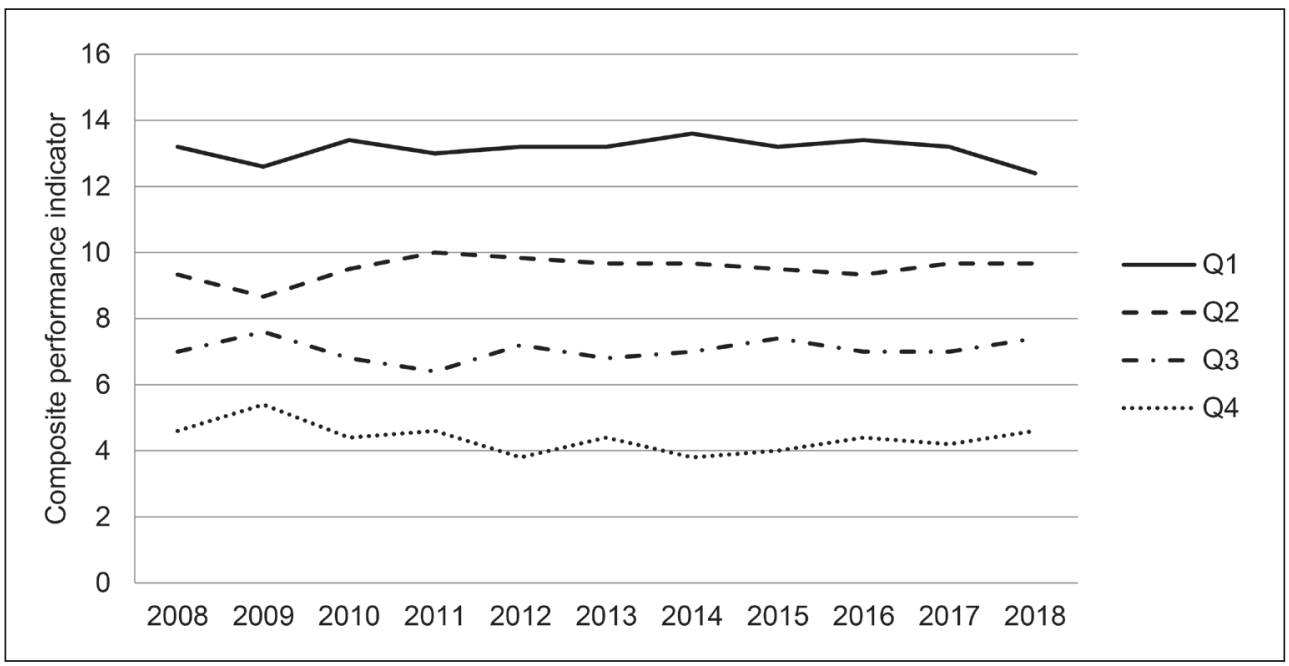




\begin{tabular}{|c|c|c|c|c|c|c|c|c|c|c|c|c|c|}
\hline Industry & 2008 & 2009 & 2010 & 2011 & 2012 & 2013 & 2014 & 2015 & 2016 & 2017 & 2018 & $\Sigma$ & Q \\
\hline Beverage production & 15 & 16 & 15 & 15 & 14 & 15 & 15 & 15 & 15 & 16 & 16 & 167 & Q1 \\
\hline Basic pharmaceutical products and preparations & 16 & 14 & 16 & 15 & 15 & 15 & 16 & 13 & 15 & 13 & 12 & 160 & Q1 \\
\hline Chemicals and chemical products & 11 & 10 & 12 & 13 & 14 & 12 & 14 & 13 & 12 & 13 & 13 & 137 & Q1 \\
\hline Other non-metallic mineral products & 15 & 13 & 13 & 11 & 10 & 11 & 11 & 12 & 12 & 12 & 12 & 132 & Q1 \\
\hline Rubber and plastic products & 9 & 10 & 11 & 11 & 13 & 13 & 12 & 13 & 13 & 12 & 9 & 126 & Q1 \\
\hline Motor vehicles, trailers and semi-trailers & 10 & 9 & 12 & 12 & 11 & 11 & 12 & 12 & 12 & 13 & 11 & 125 & Q2 \\
\hline Other transport equipment & 9 & 12 & 11 & 13 & 13 & 11 & 11 & 11 & 10 & 8 & 7 & 116 & Q2 \\
\hline Paper and paper products & 10 & 11 & 9 & 9 & 9 & 8 & 9 & 9 & 10 & 11 & 11 & 106 & Q2 \\
\hline Electrical equipment & 7 & 9 & 12 & 10 & 11 & 10 & 8 & 9 & 8 & 9 & 8 & 101 & Q2 \\
\hline Basic metals, metallurgical processing of metals & 13 & 4 & 6 & 10 & 7 & 9 & 11 & 8 & 8 & 8 & 11 & 95 & Q2 \\
\hline Fabricated metal products, except machinery & 7 & 7 & 7 & 6 & 8 & 9 & 7 & 8 & 8 & 9 & 10 & 86 & Q2 \\
\hline Printing and reproduction of recorded media & 9 & 11 & 8 & 7 & 8 & 6 & 7 & 9 & 7 & 6 & 5 & 83 & Q3 \\
\hline Computer, electronic and optical products & 6 & 5 & 5 & 6 & 7 & 7 & 10 & 9 & 8 & 8 & 7 & 78 & Q3 \\
\hline Manufacture of wood, cork, and straw products & 6 & 7 & 5 & 6 & 7 & 7 & 6 & 6 & 8 & 9 & 11 & 78 & Q3 \\
\hline Machinery and equipment not specified elsewhere & 6 & 6 & 8 & 7 & 8 & 7 & 8 & 7 & 6 & 6 & 6 & 75 & Q3 \\
\hline Other manufacturing industry & 8 & 9 & 8 & 6 & 6 & 7 & 4 & 6 & 6 & 6 & 8 & 74 & Q3 \\
\hline Wearing apparel & 6 & 6 & 6 & 6 & 6 & 6 & 6 & 6 & 6 & 6 & 6 & 66 & Q4 \\
\hline Leather and related products & 6 & 6 & 6 & 5 & 3 & 6 & 3 & 6 & 5 & 4 & 6 & 56 & Q4 \\
\hline Food products & 6 & 7 & 4 & 4 & 3 & 4 & 3 & 3 & 4 & 3 & 3 & 44 & Q4 \\
\hline Furniture production & 3 & 4 & 1 & 5 & 3 & 4 & 4 & 4 & 5 & 5 & 5 & 43 & Q4 \\
\hline Manufacture of textiles & 2 & 4 & 5 & 3 & 4 & 2 & 3 & 1 & 2 & 3 & 3 & 32 & Q4 \\
\hline
\end{tabular}

and metallurgical processing of metals, which was affected by the consequences of the financial crisis to such an extent that there was a significant drop in sales and profits compared to other sectors, which resulted in a reduction in overall performance. However, in the period of subsequent economic growth (from 2011 to 2018), this sector also reached similar values as before the financial crisis.

\subsection{Industry 4.0 Context}

The contribution of the implementation of the principles of Industry 4.0 in the context of longterm performance leading to the economic sustainability of industrial sectors can be illustrated in two very similar, but also different, industries - beverage production (Q1) and food production (Q4). The beverage industry is characterized up to three times higher investments in relation to total costs. These investments lead to a reduction in operating costs and thus increased profits in the future. By contrast, the production of food products, due to lower investments, achieves lower added value and lower turnover and profits.

It might seem that increasing the level of investment automatically leads to a reduction in costs, an increase in sales and profits in the long run, and consequently to a higher level of efficiency and independence from external sources of financing (such as subsidies). However, no other statement is further from the truth, as illustrated in Fig. 3.

Although, in general, the industries of all quartiles have a similar level of investment in total costs, the industries included in the Q1 


\section{per employee}

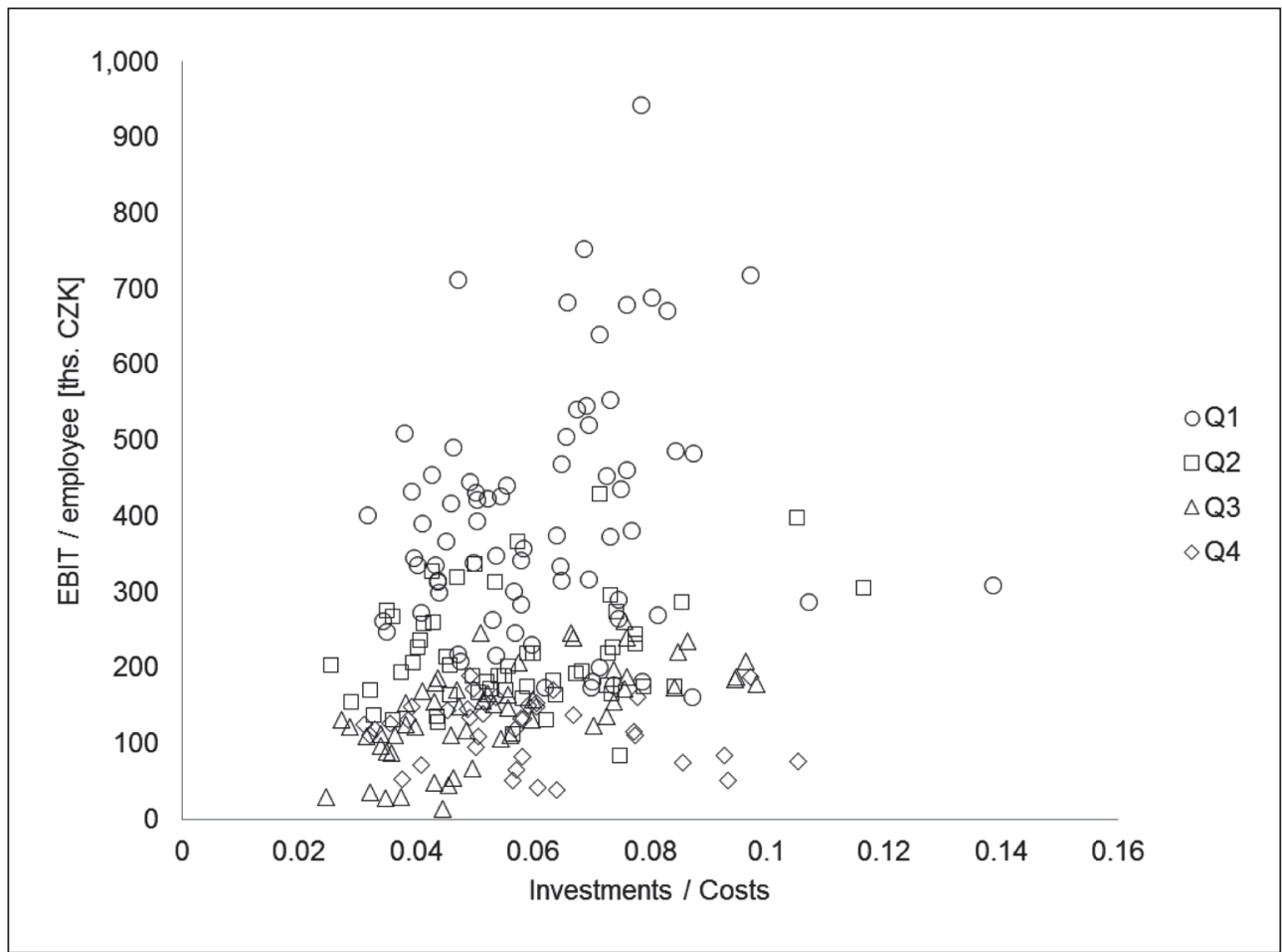

quartile show a much higher rate of profitability according to the EBIT/employee indicator. The difference is in the investment approach:

Investments in more efficient industrial sectors (Q1) are much more efficient than in others. There can be several reasons. First, more efficient investments in modern technologies, for example, lead to higher added value and thus to increased profitability. Second, investment (capital) can replace human labour and thus streamlining production. An important element from the point of view of economic efficiency is the subsequent reduction in the number of employees, which leads to a reduction in costs and thus to an increase in profit. Conversely, investing as a complement to the labour factor ultimately increases costs, but may not lead to increased profitability, as may be the case in the food or textile industries. Besides, these industries are characterized by the production of products at very low price elasticity.
Achieving higher profitability, in this case, is much more complicated than, for example, in the chemical or pharmaceutical industry.

For this reason, it is more appropriate to monitor the amount of investment per employee. If labour is replaced by capital, the number of employees decreases, and thus the total operating costs decreases, the added value increases, and profitability increases. Therefore, it can be assumed that the higher the investment per employee, the higher the profit per employee. This statement is also supported by the graphic representation, which shows the difference between the various groups of industries (Fig. 4).

A direct linear relation of these two indicators can be observed in all sectors the higher the investment per employee, the higher the EBIT per employee. At the same time, the difference between the various groups of industries is quite clear - while the 


\section{Fig. 4: The relation between investments per employee and EBIT per employee}

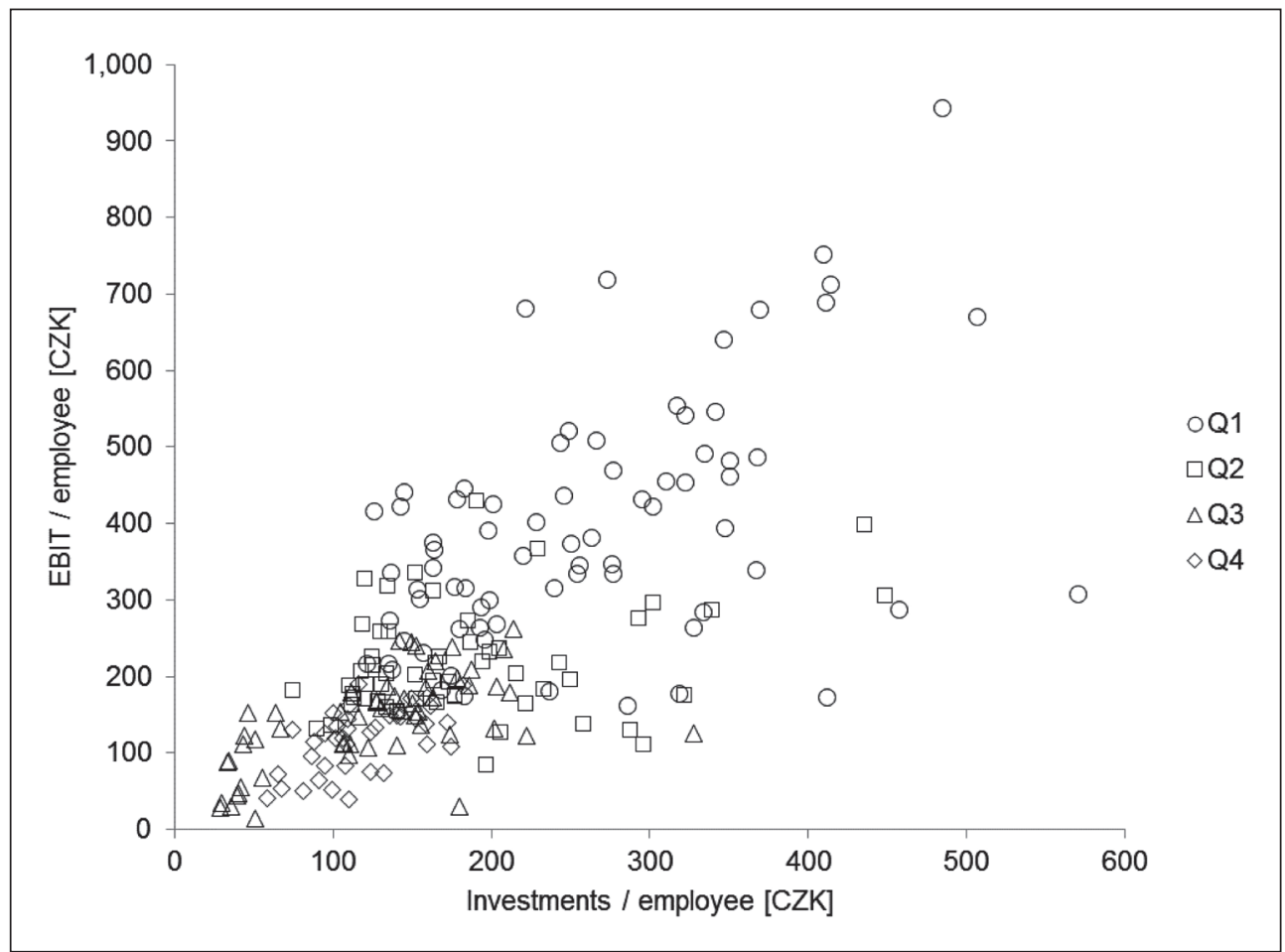

Source: own

most efficient ones achieve the highest levels of investment and profit, the least efficient industries have the lowest ratio.

Specifically, we can mention, for example, the production of chemicals and chemical preparations, the pharmaceutical industry and the production of beverages - these sectors have achieved one of the highest profits per employee in the long run. From the point of view of the concept of industry 4.0 , the production of beverages in comparison with food production is particularly interesting. In comparison with food production, the production of beverages is associated with a relatively high rate of capital utilization and a relatively low rate of human labour. On the contrary, the food industry, but also the production of furniture or textiles, achieves the lowest profits, as it is highly dependent on human labour and a high share of investment in these areas does not bring such significant added value compared to other sectors (higher added value leads to higher profits) see Fig. 5.

Given these findings, it can be stated that some less efficient industries (see Tab. 3) do not achieve the desired results (added value, profit) despite a relatively significant share of investment in total costs. At a time of economic growth, this is not a big problem. Unfortunately, this problem can become significant in times of economic recession. For example, most economic operators are now starting to save more, postpone purchases or prefer cheaper products. However, cheaper products are usually the result of more efficient production. If some industries do not invest in streamlining production, but only renew current amount of capital, there is a significant risk that they will not be able to compete with, for example, production from abroad. Thus, some less efficient industries will face difficulties and become economically "unsustainable" 


\section{Fig. 5: The relation between investments per employee and added value per employee}

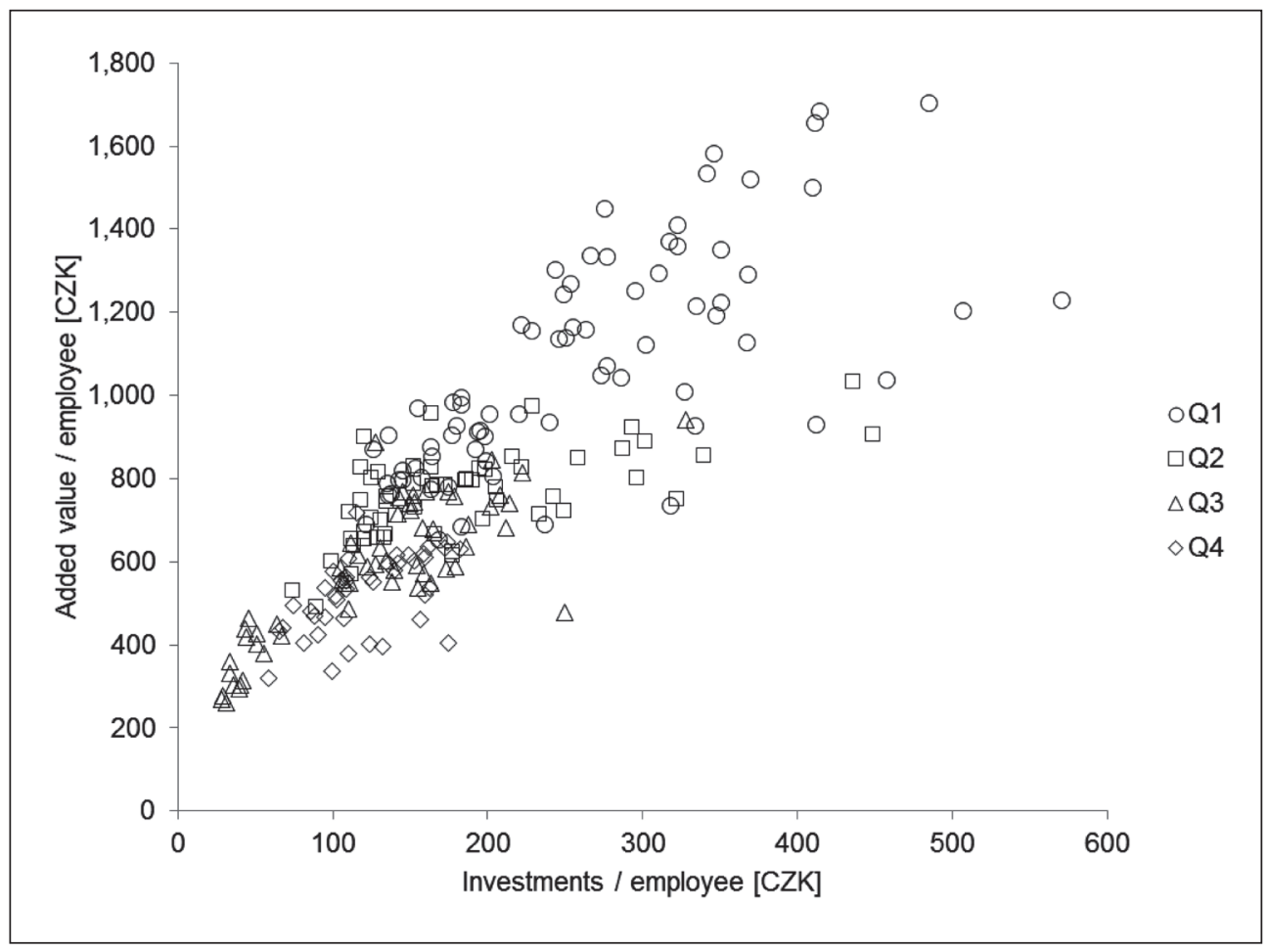

Source: own

because they do not have the high profits needed to build up the necessary reserves, even in times of economic growth. Although, the tools to address this potential situation exist (for example, the already mentioned state interventions, restructuring, or others), from an economic point of view, it will be a form of failure that will only distort the market more in the future.

\section{Discussion and Conclusion}

Nowadays, more and more attention is being paid to the Industry 4.0 initiative, which is also called the Fourth Industrial Revolution. This initiative brings with it a significant contribution to new technologies as well as to innovations by substituting labour by capital. Currently, there is also constant pressure to increase the efficiency and profitability of production while declining costs. Related to this is a fundamental question - how to measure and evaluate the results of management in the manufacturing industry and the performance of its sectors.

For this reason, a review of the literature was performed to present industrialization in selected countries. At the same time, the indicators used for economic efficiency measuring was presented. Attention was also paid to specific procedures for measuring efficiency and related findings (e.g., characteristics of selected indicators, number, etc). The common benefits of all methods for evaluating efficiency and performance are obtaining information that can be used, for example, by company management, and by political representatives, and thus collecting useful information about companies' performance in individual industries. Unfortunately, the methods of performance evaluation that are different sectors, there is no comprehensive assessment of their performance in a way that will not be affected 
by short-term economic fluctuations (Zizlavsky, 2016). This information is essential for defining industries in which development is inefficient or uncompetitive in the long run.

Based on selected eight KPIs, which have already been used to evaluate performance in the manufacturing industry, a total of 6 indicators were identified as statistically significant through cluster analysis and analysis of variance. Therefore, these indicators were used in the proposed framework to calculate the composite performance indicator. The procedure for determining this composite indicator is based on a cross-sectoral comparison of each performance indicator's values. This method eliminates short-term economic effects that may cause rapid growth or decline in some indicators' values. The value of the composite performance indicator can be used for the identification of long-term trends in the performance development of all branches of the manufacturing industry subsequently.

The most productive sectors (Q1) are the beverage production, basic pharmaceutical industry, and chemical industry, and the least productive areas (Q4) include, for example, the food products industry, furniture industry, and manufacture of textiles. The difference between the performance of individual sectors is given both by the amount of investment in relation to total costs and in the added value created. Industry 4.0 initiative (promoting new technologies and robotization of production) is applied mainly in the better-rated sectors. In other industries, investment in the capital is inefficient; to a large extent, these investments are only supplements to human labour or a simple renewal of capital without significant technological improvement. In terms of longterm development, only some industries continue to reduce operating costs and increase profits and increase production efficiency.

Based on the results of this research, the assumption that with the increasing level of investment in production will automatically be a long-term reduction in costs, an increase in revenues, and thus an increase in profits, is wrong in the long run. Although all industries have achieved an equal share of investments in total costs since 2008, the industries included in the Q1 quartile show a much higher rate of profitability than others. The main explanatory factors are the greater emphasis on raising the technological level and substitution of labour by capital - the industries of the Q1 quartile replace labour with capital (i.e., they reduce the number of employees while maintaining a high level of added value) to a much greater extent than all others, leading to the highest level of profitability. For this reason, we propose to monitor and focus mainly on the efficiency of investments rather than on their absolute values. The solution is to monitor the amount of investment in relation to one employee when substituting labour with capital, there is a reduction in the number of employees (and thus a reduction in expenditure costs), and at the same time, there is an increase in labour productivity, which leads to higher returns and profitability. The higher the investment per employee, the higher the profit per employee.

Less efficient industries, which are much more dependent on the workforce (e.g., textile industry, furniture industry, wearing apparel, food production), can easily get into economic trouble in the long run due to fluctuations in economic cycles - a decrease in demand leads to a decrease in sales, but due to low elasticity on the labour market, wages do not decrease, which usually leads to a decrease in profit. This is currently evident in the coronavirus pandemic. Many sectors face problems because they have to pay wages to their employees, even though these employees, for example, do not even produce any added value due to government intervention. These sectors, such as those related to tourism and hospitality, are thus dependent on external interventions (e.g., the government in the form of subsidies or other guarantees, more available loans, etc), which will fundamentally distort the free market. However, for many sectors, this aid can be like a drug, without which they could not otherwise exist in a dynamic environment. Low profits also lead to complex provisioning. There is a potential lack of funds for further development and investment, which would allow them to adapt to current trends. Evidence of this is, for example, the current coronavirus pandemic, which is causing very significant losses in many sectors, which are an existential threat to many companies in various industries.

The limitation of this study is that the measurement of the company's performance is burdened by a certain inaccuracy associated with the creative nature of this process. And there are other factors, such as the associated risks and transaction costs, that can affect 
a company's performance rating (GuerolaNavarro et al., 2020). However, it should be noted that given the importance of the innovative process for the development of the company and the number of resources invested in it, it is necessary to measure performance in this area. Given the importance of the innovative process for the development of the company and the number of resources invested in it, measuring performance from the manufacturing industry is essential (Zizlavsky, 2016). Another important aspect that will have an impact on measuring the performance of companies and accelerating digitization and robotics is the current Covid-19 pandemic, which will accelerate the introduction of new ICT and robots in companies.

Acknowledgements: This research was funded by the project SPEV 2021 at the Faculty of Informatics and Management of the University of Hradec Králové, Czech Republic.

\section{References}

Ali, A. I., \& Nakosteen, R. (2005). Ranking industry performance in the US. SocioEconomic Planning Sciences, 39(1), 11-24. https://doi.org/10.1016/j.seps.2003.10.003

Al-Tmeemy, S. M. H. M., Abdul-Rahman, H., \& Harun, Z. (2011). Future criteria for success of building projects in Malaysia. International Journal of Project Management, 29(3), 337-348. https://doi.org/10.1016/j. ijproman.2010.03.003

Amrina, E., \& Yusof, S. M. (2011). Key performance indicators for sustainable manufacturing evaluation in automotive companies. In Proceeding of the 2011 IEEE International Conference on Industrial Engineering and Engineering Management (pp. 1093-1097). Singapore. https://doi. org/10.1109/IEEM.2011.6118084

Asmalovskij, A., Sadílek, T., Hinčica, V., \& Mizerová, M. (2019). Performance of Social Enterprises in the Czech Republic. Journal of Social Entrepreneurship, 10(1), 19-29. https:// doi.org/10.1080/19420676.2018.1521865

Association of Small and Medium-sized Enterprises and Self-employed Persons of the Czech Republic. (2019). Analýza průmyslu 2019 - Asociace malých a středních podniků. https://amsp.cz/vyplati-se-malym-a-strednimpodnikum-digitalizovat-vyrobu-2/

Bod'a, M., \& Úradníček, V. (2020). Methodology of Industry Statistics: Averages,
Quantiles and Responses to Atypical Value. E\&M Economics and Management, 23(3), 120-137. https://doi.org/10.15240/tul/001/2020-3-008

Braz, R. G. F., Scavarda, L. F., \& Martins, R. A. (2011). Reviewing and improving performance measurement systems: An action research. International Journal of Production Economics, 133(2), 751-760. https://doi. org/10.1016/j.ijpe.2011.06.003

Chan, A. P. C., \& Chan, A. P. L. (2004). Key performance indicators for measuring construction success. Benchmarking: An International Journal, 11(2), 203-221. https://doi.org/10.1108/14635770410532624

Chan, A. P. C., Scott, D., \& Chan, A. P. L. (2004). Factors Affecting the Success of a Construction Project. Journal of Construction Engineering and Management, 130(1), 153-155. https://doi.org/10.1061/(ASCE)07339364(2004)130:1(153)

Cheung, S. O., Suen, H. C. H., \& Cheung, K. K. W. (2004). PPMS: A Web-based construction Project Performance Monitoring System. Automation in Construction, 13(3), 361-376. https://doi.org/10.1016/j.autcon.2003.12.001

Czech Statistical Office. (2019). 293/2019 Sb Decree on the Program of Statistical Surveys for 2020. Prague: Czech Statistical Office.

Eurofond. (2020). Industrial relations index. Eurofond. https://www.eurofound.europa.eu/ data/Industrial-relations-index period $=2013$ 2017\&breakdown=index\&mode=all\&country=all

Falle, S., Rauter, R., Engert, S., \& Baumgartner, R. (2016). Sustainability Management with the Sustainability Balanced Scorecard in SMEs: Findings from an Austrian Case Study. Sustainability, 8(6), 545. https://doi. org/10.3390/su8060545

Ferreira, L. M. D. F., Silva, C., \& Azevedo, S. G. (2016). An environmental balanced scorecard for supply chain performance measurement (Env_BSC_4_SCPM). Benchmarking: An International Journal, 23(6), 1398-1422. https://doi.org/10.1108/BIJ-08-2013-0087

Flynn, J., Dance, S., \& Schaefer, D. (2017). Industry 4.0 and Its Potential Impact on Employment Demographics in the UK. In J. Gao, M. E. Souri, \& S. Keates (Eds.), Advances in Manufacturing Technology XXXI: Proceedings of the 15th International Conference on Manufacturing Research, incorporating the 32nd National Conference on Manufacturing Research, September 5-7, 2017, University of Greenwich, UK. Amsterdam: IOS Press. 
Franceschini, F., Galetto, M., \& Maisano, D. (2007). Management by Measurement Designing Key Indicators and Performance Measurement Systems. http://www.vlebooks.com/vleweb/product/ openreader?id=none\&isbn=9783540732129

Globerson, S. (1985). Issues in developing a performance criteria system for an organization. International Journal of Production Research, 23(4), 639-646. https://doi.org/10.1080/00207548508904734

Graham, I., Goodall, P., Peng, Y., Palmer, C., West, A., Conway, P., Mascolo, J. E., \& Dettmer, F. U. (2015). Performance measurement and $\mathrm{KPIs}$ for remanufacturing. Journal of Remanufacturing, 5(1), 10. https:// doi.org/10.1186/s13243-015-0019-2

Guerola-Navarro, V., Oltra-Badenes, R., Gil-Gomez, H., \& Gil-Gomez, J. A. (2020). Research model for measuring the impact of customer relationship management (CRM) on performance indicators. Economic Research Ekonomska Istraživanja, 1-23. https://doi.org/1 0.1080/1331677X.2020.1836992

Hálek, V., Borkovcová, A., \& Hašek, F. (2020). Non-financial Indicators in the Valuation Process - Actual Trends. E\&M Economics and Management, 23(1), 60-74. https://doi. org/10.15240/tul/001/2020-1-005

Hedvičáková, M., \& Král, M. (2019). Benefits of KPIs for Industry Sector Evaluation: The Case Study from the Czech Republic. E\&M Economics and Management, 22(2), 97-113. https://doi.org/10.15240/tul/001/2019-2-007

Hope, J., \& Fraser, R. (2003). Beyond budgeting: How managers can break free from the annual performance trap. Brighton, MA: Harvard Business School Press.

Hristov, I., \& Chirico, A. (2019). The Role of Sustainability Key Performance Indicators (KPIs) in Implementing Sustainable Strategies. Sustainability, 11(20), 5742. https://doi. org/10.3390/su11205742

Hristov, I., Chirico, A., \& Appolloni, A. (2019). Sustainability Value Creation, Survival, and Growth of the Company: A Critical Perspective in the Sustainability Balanced Scorecard (SBSC). Sustainability, 11(7), 2119. https://doi. org/10.3390/su11072119

Hsu, C.-H., Chang, A.-Y., \& Luo, W. (2017). Identifying key performance factors for sustainability development of SMEs integrating QFD and fuzzy MADM methods.
Journal of Cleaner Production, 161, 629-645. https://doi.org/10.1016/j.jclepro.2017.05.063

Huff, R. F. (2011). Measuring Performance in US Municipalities: Do Personnel Policies Predict System Level Outcomes? Journal of Comparative Policy Analysis: Research and Practice, 13(1), 11-33. https://doi.org/10.1080/ 13876988.2011.538535

Jahangirian, M., Taylor, S. J. E., Young, T., \& Robinson, S. (2017). Key performance indicators for successful simulation projects. Journal of the Operational Research Society, 68(7), 747-765. https://doi.org/10.1057/jors.2016.1

Kang, N., Zhao, C., Li, J., \& Horst, J. A. (2016). A Hierarchical structure of key performance indicators for operation management and continuous improvement in production systems. International Journal of Production Research, 54(21), 6333-6350. https://doi.org/10.1080/002 07543.2015.1136082

Kaplan, R. S., \& Norton, D. P. (1992). The Balanced Scorecard - Measures that Drive Performance. Harvard Business Review, 1992(70), 71-79.

Karl, A. A., Micheluzzi, J., Leite, L. R., \& Pereira, C. R. (2018). Supply chain resilience and key performance indicators: A systematic literature review. Production, 28, e20180020. https://doi.org/10.1590/0103-6513.20180020

Kumaraswamy, M., Mahesh, G., Mahalingam, A., Loganathan, S., \& Kalidindi, S. N. (2017). Developing a clients' charter and construction project KPIs to direct and drive industry improvements. Built Environment Project and Asset Management, 7(3), 253-270. https://doi.org/10.1108/BEPAM-02-2017-0013

Lam, E. W. M., Chan, A. P. C., \& Chan, D. W. M. (2007). Benchmarking the performance of design-build projects: Development of project success index. Benchmarking: An International Journal, 14(5), 624-638. https:// doi.org/10.1108/14635770710819290

Lindberg, C.-F., Tan, S., Yan, J., \& Starfelt, F. (2015). Key Performance Indicators Improve Industrial Performance. Energy Procedia, 75, 1785-1790. https://doi.org/10.1016/j. egypro.2015.07.474

Luu, V. T., Kim, S.-Y., \& Huynh, T.-A. (2008). Improving project management performance of large contractors using benchmarking approach. International Journal of Project Management, 26(7), 758-769. https://doi. org/10.1016/j.jproman.2007.10.002 
Maresova, P., Soukal, I., Svobodova, L., Hedvicakova, M., Javanmardi, E., Selamat, A., \& Krejcar, O. (2018). Consequences of Industry 4.0 in Business and Economics. Economies, 6(3), 46. https://doi.org/10.3390/ economies6030046

Neely, A., Gregory, M., \& Platts, K. (1995). Performance measurement system design: A literature review and research agenda. International Journal of Operations \& Production Management, 15(4), 80-116. https://doi.org/10.1108/01443579510083622

Parmenter, D. (2015). Key performance indicators: Developing, implementing, and using winning KPIs (3rd ed.). Hoboken, $\mathrm{NJ}$ : Wiley.

Pavelková, D., Homolka, L., Knápková, A., Kolman, K., \& Pham, H. (2018). EVA and Key Performance Indicators: The Case of Automotive Sector in Pre-Crisis, Crisis and Post-Crisis Periods. Economics \& Sociology, 11(3), 78-95. https://doi.org/10.14254/2071789X.2018/11-3/5

Peral, J., Maté, A., \& Marco, M. (2017). Application of Data Mining techniques to identify relevant Key Performance Indicators. Computer Standards \& Interfaces, 50, 55-64. https://doi.org/10.1016/j.csi.2016.09.009

Peruzzini, M., Grandi, F., \& Pellicciari, M. (2017). Benchmarking of Tools for User Experience Analysis in Industry 4.0. Procedia Manufacturing, 11, 806-813. https://doi. org/10.1016/j.promfg.2017.07.182

PriceWaterhouseCoopers. (2007). Guide to key performance indicators - Communicating the measures that matter. 2007. https://www. academia.edu/10347249/Guide_to_key_ performance_indicators_Communicating_the measures_that_matter_connectedthinking_ pwc

Rajnoha, R., Lesníková, P., \& Krajčík, V. (2017). Influence of business performance measurement systems and corporate sustainability concept to overal business performance: "Save the planet and keep your performance". E\&M Economics and Management, 20(1), 111-128. https://doi. org/10.15240/tul/001/2017-1-008

Raynsford, N. (2000). KPI Report for The Minister for Construction by the KPI Working Group. KPI Working Group. https://assets. publishing.service.gov.uk/government/uploads/ system/uploads/attachment_data/file/16323/ file16441.pdf
Robbins, G., Turley, G., \& McNena, S. (2016). Benchmarking the financial performance of local councils in Ireland. Administration, 64(1), 1-27. https://doi.org/10.1515/admin-2016-0009

Sorovou, C., Politou, D., Kalligeris, A., \& Topouzidou, S. (2001). D3-KPI Manual Part I General Methodology. IST-2000-28760.

The Ministry of Industry and Trade of the Czech Republic. (2018a). Panorama of the Manufacturing Industry of the Czech Republic 2018. https://www.mpo.cz/assets/en/industry/ manufacturing-industry/panorama-of-themanufacturing-industry/2019/10/panorama_aj_ web.pdf

The Ministry of Industry and Trade of the Czech Republic. (2018b). Panorama zpracovatelského prümyslu ČR 2018 [Panorama of the Manufacturing Industry of the Czech Republic 2018] (1st ed., Vol. 22). Prague: The Ministry of Industry and Trade of the Czech Republic.

Turley, G., Robbins, G., \& McNena, S. (2015). A Framework to Measure the Financial Performance of Local Governments. Local Government Studies, 41(3), 401-420. https:// doi.org/10.1080/03003930.2014.991865

Vimrová, H. (2015). Financial Analysis Tools, from Traditional Indicators through Contemporary Instruments to Complex Performance Measurement and Management Systems in the Czech Business Practice. Procedia Economics and Finance, 25, 166-175. https://doi.org/10.1016/S22125671(15)00725-X

Woerd, F. V. D., \& Brink, T. v. d. (2004). Feasibility of a Responsive Business Scorecard: A pilot study. Journal of Business Ethics, 55(2), 173-186. https://doi.org/10.1007/s10551-0041900-3

Zafra-Gómez, J. L., López-Hernández, A. M., \& Hernández-Bastida, A. (2009). Evaluating financial performance in local government: Maximizing the benchmarking value. International Review of Administrative Sciences, 75(1), 151-167. https://doi. org/10.1177/0020852308099510

Zhu, L., Johnsson, C., Mejvik, J., Varisco, M., \& Schiraldi, M. (2017). Key performance indicators for manufacturing operations management in the process industry. In 2017 IEEE International Conference on Industrial Engineering and Engineering Management (pp. 969-973), Singapore. https://doi.org/10.1109/ IEEM.2017.8290036 
Zhu, L., Johnsson, C., Varisco, M., \& Schiraldi, M. M. (2018). Key performance indicators for manufacturing operations management - gap analysis between process industrial needs and ISO 22400 standard. Procedia Manufacturing, 25, 82-88. https://doi. org/10.1016/j.promfg.2018.06.060
Zizlavsky, O. (2016). Innovation performance measurement: Research into Czech business practice. Economic Research - Ekonomska Istraživanja, 29(1), 816-838. https://doi.org/10. 1080/1331677X.2016.1235983 